University for Business and Technology in Kosovo

UBT Knowledge Center

UBT International Conference

2017 UBT International Conference

Oct 28th, 11:00 AM - 12:30 PM

\title{
The value of inclusive education in Kosovo
}

Alma Lama

South East European University, al21449@seeu.edu.mk

Follow this and additional works at: https://knowledgecenter.ubt-uni.net/conference

Part of the Education Commons

\section{Recommended Citation}

Lama, Alma, "The value of inclusive education in Kosovo" (2017). UBT International Conference. 110.

https://knowledgecenter.ubt-uni.net/conference/2017/all-events/110

This Event is brought to you for free and open access by the Publication and Journals at UBT Knowledge Center. It has been accepted for inclusion in UBT International Conference by an authorized administrator of UBT Knowledge Center. For more information, please contact knowledge.center@ubt-uni.net. 


\title{
The value of inclusive education in Kosovo
}

\author{
Alma V.Lama ${ }^{1}$ \\ South East University Tetovo, Macedonia \\ a121449@seeu.edu.mk
}

\begin{abstract}
Inclusive education is a great deal in all countries around the world which aim to treat everyone the same, have equal opportunities for all children regardless of race, sex, religion or any other diversity.

In Kosovo, inclusive education has become a reality as a concept but is facing numerous difficulties in making efforts toward the realization.

The purpose of this study is to understand the value and effect of inclusion in students with learning disabilities in general education and its environment. This study is intended to listen to the understanding of the teachers on inclusion and base on that recommend what needs to be done in order to continually encourage inclusion in the regular classroom.

So through this paper we will understand the potential and the value of inclusive education into a regular education!

This study contains critical analysis of research, a comprehensive review and a literature review concerning the issue of all inclusive education, some factors that helped the movement to educate students in inclusive classroom, models of how an inclusive classroom should look like, the value of all students, the attitude of regular students and regular teachers when placing students with disabilities into a regular classroom.
\end{abstract}

Keywords: Inclusive Education, Disability, Difficulties

\section{Introduction}

In the past, in Kosovo, the education of children with learning disabilities were included in one term as "children with special needs" have attended special education classes. As a result, these children have remained isolated from the society and they were not given an opportunity to socialize or benefit from students with normal intelligence; or ready to join the larger or heterogeneous communities in which they could live and work for the rest of their lives.

In fact, the special education in Kosovo has been running sinc1950 but the education in these special schools was offered for a small number of children considering the small number of schools and the non-professional staff.

In a period of 1990-1999 there were four special schools and four attached classes in the context of regular schools that have functioned. Since 2000, there were great changes that took place in Kosovo Education and one of those was to separate children with learning difficulties and those are children who have mental health problems, for example anxiety, or have additional developmental disorders, verses those that have mental illness. This idea was supported by Ministry of Science and Technology, firstly under the governing of UNMIK and some international organizations such as Save the Children, Finnish Support to the Development of Education in Kosovo (known as "FSDEK"), UNICEF, Handikos, etc. The period after 2000, marks a great progress towards the development of a series of documents by the Ministry of Education, Science and Technology which have been boldly oriented towards the inclusion. 


\section{Inclusion}

Inclusion is understood as a strategy that students with disabilities should be integrated into the regular education classrooms whether or not they can meet regular curricular standards therefore Ministry of Education together with its cabinet made it possible that education in Kosovo should be in line with modern education trends so these students have to be integrated into a society through inclusive education.

Since every child has a right on education, inclusive education has become an integral part of all policies of the Ministry of Education, Science and Technology in Kosovo. Ministry of Education in Kosovo continually tries to implement the best practice and this practice normally involves teachers as they are asked to educate all students in inclusive classroom.

Research has shown that all inclusive classes contribute to the idea that students with disabilities should be part of regular classes and provide assistance when necessary or when the lesson is hard to comprehend.

However before any school can implement a program, they need reliable evidence that the new program will work as it is strongly related to people's attitudes whether they are positive or negative as this results on its effectiveness.

In order to improve the inclusion program, the school should provide appropriate training so everyone involved find the school a place that is fun to be.

\section{Inclusive outside of Kosova}

In other countries inclusive education begun in the previous century!

According to (Lipsky \& Gartner, 1997,p73) "In United States, Special education began in 1823" and between 1905 to 1920,cities such as New York and Cleveland begun to accommodate schools for students who have difficulties in learning due to cognitive problem, social issues or those who were hard to be teachable.

Then in 1960's different studies were published questioning the benefit of special classes for children with cognitive issues. Lipsky and Gartner(1997) brought a conclusion such as:

There is no evidence that the academic progress for children with disability was better than the academic progress of children in general classroom.

General education is capable of providing effective individual instruction to those with cognitive issues. With this in mind in 1973 the Vocational Rehabilitation Act was formed as a civil right law. According to Friend \& Bursuck,(1999). "This law prevents discrimination against all individuals with disabilities in programs that receive federal funds, as do all public schools" This law has enforced the right to a free appropriate public education for all students with disabilities. Today, the present trend in special education is toward inclusive practices with the best interests of each individual student in mind.(Friend \& Bursuck,1999)Together with this change, according to Salend (2001), there were also concerns about inclusive education for example the negative attitude of others, lack of training, the number of students in the class, the impatience of normal intelligence students, difficulties in meeting the behavioral challenges of students with disabilities and in designing and implementing appropriate instructional accommodations. Salend (2001) also expressed that general education teachers have also expressed outcomes of inclusion which include increased confidence in their teaching, great awareness as a positive role models, advanced more in meeting needs of all students etc. So, successful inclusive education 
relies also on teachers as well as parents in order to adapt and integrate students with disabilities into a regular education classroom and to fill the gaps and barriers of learning.

\section{Statement of the problem}

This study seeks to explore the effect of inclusive education in children with disabilities. This study will affect both groups of students, educators and parents in daily basis and it is known as the center of much controversy in the field of education.

\section{Purpose of the study}

The purpose of this study is to help educators and parents more clearly to understand the concept of inclusion and the benefits of placing students with different learning difficulties into regular education classrooms. This would be accomplished through a comparative study of the research and literature associated with inclusion as well as special education and regular education.

\section{Research objectives}

This study aims to:

- $\quad$ To examine the effects of inclusive education between students with learning difficulties and with those with normal intelligence in a regular classroom

- To examine if Kosovo has trained teachers for inclusive education

- To encourage parents' involvement so they can build a bridge between home and school-based atmosphere.

- To bring recommendations in order to help teachers come together in a positive way regarding the concept of inclusion.

Once we have developed a clear understanding of the strategies, we can use sample lessons to reference before beginning with any other implementation strategies which focus is always to improve student achievement, allow teachers to have a wide range of instructional alternatives, promote learning methods and help integrate students with learning difficulties into a higher academic level.

\section{Research Questions}

The aim of this study is to describe the effect that inclusive education have in students who encounter difficulties in learning due to their disability.

- How does inclusive education promote successful learning

- How does education need to change to accommodate all students the same?

- What can be done to encourage teachers' position in inclusive education? 


\section{Literature Review}

The purpose of this literature review is to gain a better understanding of what inclusion is, what inclusion is not and to discuss the potential advantages and disadvantages of inclusion.

The understanding of inclusive education in international development, the European Agency for Special Needs and Inclusive Education (2013) further points out that inclusion is not only about placement of a child (either in a special education setting or regular classrooms), but is about learning and social inclusion.

According to Salamanca Statement (1994) " Regular schools with inclusive orientation are the most effective means of combating discriminatory attitudes, creating welcoming communities, building an inclusive society and achieving education for all."

However, while education in the mainstream school is adopted as a norm for inclusive education, the United Nations Convention on the Rights of Persons with Disabilities CRPD (2006) refers that all disabled children must be able to "access an inclusive, quality, free primary and secondary education on an equal basis with others in the communities in which they live," This suggests that schools need to be ready to respond to the individual differences and adapt in the curriculum content, objectives, assessments and classroom management so the learning can take place.

The inclusive education can be rewarding too, yet there is a difficult journey to create an educational system where excellence and equality walk hand in hand (Frost \& Pearpoint, 2004) In Kosovo, steps toward an inclusive education are still understood just in a concept and they are in process . This process, however, is facing some obstacles especially in the adequate conception of the inclusive education concept by the education institutions starting from the lowest level to the high school level. The inclusion needs to be seen a model for reaching all the students and as something that provides everyone with equal opportunities to quality education. Through the last past decade, the inclusion has been at the epicenter of debate among educators and parents. Ministry of Education, Science and Technology in Kosovo, included the inclusive education as a philosophy which permeates all its policies, from the legislation to the other accompanying documents promoting the inclusive education

\section{What is Inclusion?}

Inclusion is a "philosophy that brings students, families, educators and community members together to create schools and other social institutions based on acceptance, belonging and community"(Salend,2001,p5).

It is worth to mention that inclusion is not focused only on students with disabilities but if implemented correctly it is also designed to be able to accommodate and respond to the needs of regular education students as well.

Salend(2001) points out four ways that provide a great framework and summarizes the philosophies on which inclusive practices are based:

- Diversity - inclusion improves the educational system for all students regardless of their ethnicity, linguistic ability, gender, learning style or cultural background while placing them together in general education classrooms.

- Individual Needs - inclusion here involves sensitivity to while meeting individual needs and differences as we know that educators cannot teach students without taking into account the factors that shape their students and make them unique.

- Reflective practice - here inclusion requires educators to be more reflective and modify their attitudes, their classroom management and the curriculum to accommodate individual needs. 
- Collaboration - involves collaboration among educators and other professionals, students and families and also community. All of this support can be provided in a regular classroom.

\section{Why is inclusion controversial?}

Topics in education also create controversy as inclusion take place. Few professionals has also question the appropriateness of including students with disabilities in regular education classrooms (Friend \& Bursuck, 1999)"However, considerable debates still continue about which students should be part of general education classes and how much time they should spend there"(Friend\&Bursuck,1999,p.14). They also state that " to say that all students should be in general education settings is to deny the unique characteristics of students with disabilities, and it denies them the right to an individual education.

\section{Three Models of Inclusion}

Surely there are different models that educators use in inclusive classroom. According to Lipsky \& Garter(1997) has brought the following models for general education and special education teachers to follow when implementing inclusion in any classroom.

- $\quad$ Consultant Model - here the teacher is trained to re-teach a difficult skill or to the student according to his need. Regularly scheduled meeting are also recommended rather than just communication as needed.

- $\quad$ Team Model - here the teacher provides student information, possible instructional strategies, different modification ideas for assignments or tests and also behavior strategies.

- $\quad$ Co- Teaching Model - Here teachers use the model of regular education to meet the needs of students with disabilities and regular students.

\section{What Does an Inclusive Classroom Look Like?}

Inclusive classroom look different all of the time because the environment is created according to the learning strategies which are assigned for example as a group, pair work or individual learning strategy. The classroom is always students centered as inclusive education cannot be oriented according to traditional learning style.

\section{Methodology}

Understanding that all children are unique and the also learn different. For us as teachers, it is important to use different methods that suit students' competence, knowledge and context.

Through this study we will explore, analyze and describe how does inclusive classroom affect students with disabilities and in addition to search the obstacles that teachers face in inclusive education.

This study will use varied research methods to collect data such as observation, interview and group focus. The observation will be done in a passive way through desk observation.

In fact, this study will take many extra steps in order to ensure the results from the data collection but it is worth to mention that qualitative approach will allow us to see more learning strategies 
that teacher can use according to the need of the student and best suited to assessing the extent of change of teacher's behavior and their attitudes toward inclusion. Methods that will be used in this research will be through observation, interview and focus group.

Observation - will be called as self observation and it will provide in-depth information the idea of how much training was provided to every teacher and qualitative research will show if the provided training for teachers have been the proper one to the real needs of quality instruction. Through seeing, hearing and touching, the observer can regularly observe the behavior of all in the class, listen to and participates in conversations, makes short interviews with people, gain understanding about the group culture and gathers data about all of it. So, through observation, we could gain a sense of what has been done, or is to be done in the class.

Interview - will have a rigid procedure where all questions will be the same for all teachers but they will fill the form separately from each other so we can a real data collection. The questions of the interview will be well structured. The data collection of the interview will provide a multiperspective understanding, the benefits and the effect that inclusive education has in the school. Focus group will be used as a method on their own or in combination with single interviews. The focus group will be examined through a questionnaire so we can get participants' interpretations of results. The questionnaire will be well structured and flexible where participants freely can express their thoughts.

\section{Conclusion}

Although in the last two decades a lot of changes have taken place in our schools starting from the number of students in the class, it is important to mention that inclusive classroom also has brought a big change not only in a theoretical way but also in a social way but there is still a necessity for more changes and supplements in school to raise the education level of teachers and students. From the study we can see that inclusion classroom gives value to diversity, and it provides a unique contribution, safety and a sense of belonging to each student individually.

By the research we can conclude that the cooperation with parents and the use of different teaching methods, forms of assessments will help on filling the gaps of the past.

\section{References}

1. “A Inclusion and school reform”(1997) Lipsky D \& Gartner

2. "Benefits of inclusive education for all”.(1999). Retrieved December 2016 from the World Wide Web: http://www.kidstogether.org/inclusion.htm

3. "Inclusion! The Bigger Picture". (2004) Forest,M.\&Pearpoint,J. Retrieved from World Wide Web

4. http://inclusion.com/artbiggerpicture.html

5. "Learning Disabilites" (1994) G. Reid Lyon Retrieved December 2016 from World Wide Web

6. http://www.futureofchildren.org/publications/docs/06_01_03.pdf

7. “Special Education Inclusion"(2001) Retrieved December 2016 from the World Wide Web http://weac.org/articles/specialedinc/

8. Note: This paper was originally written in 2001 by Katie Schultz Stout, then WEAC's Director of Instruction and Professional Development. It is continuously monitored and updated periodically by Joanne Huston, Teaching and Learning Consultant/ Legal Counsel 
9. "Philosophy of inclusive education".(2004). Retrieved December 2016 from the World Wide Web

10. http://www.specialeducationguide.com/pre-k-12/inclusion/whats-inclusion-theory-andpractice/

11. "The Inclusion Facilitator's Guide”.(2005). Cheryl M. Jorgensen Ph.D., Mary C. Schuh Ph.D., and Jan Nisbet Ph.D. Retrieved December 2016 from the World Wide Web

12. http://archive.brookespublishing.com/documents/Inclusion_facilitator's_Guide_CH1.pdf 